УДК 633.12:631.527.8 DOI 10.31210/visnyk2018.03.13

(C) 2018

Тригуб О. В., кандидат сільськогосподарських наук

Устимівська дослідна станція рослинництва

Ляшенко В. В., кандидат сільськогосподарських наук,

Бараболя О. В., кандидат сільськогосподарських наук

Полтавська державна аграрна академія

\title{
СЕЛЕКЦЙНА ЦІННІСТЬ ЕКОЛОГІЧНО ВІДДАЛЕНИХ ЗРАЗКІВ ГРЕЧКИ НАЦІОНАЛЬНОЇ КОЛЕКЦІї УКРАЇНИ
}

\section{Рецензент - кандидат сільськогосподарських наук А. В. Баган}

\begin{abstract}
Наведено результати вивчення колекційного матеріалу гречки Начіональної колекиї Украӥни різного еколого-географічного походження за господарськими та селекційно-иінними показниками. Проведено розподіл генофонду групи вивчення в залежності від екологічної приналежності сортів та форм. Із усього різноманіття виділено найбільш цінні зразки, які можна рекомендувати як джерела цінних ознак із підвищеними параметрами урожайності, продуктивності рослини, крупноплідності, щео поєднуються із високою вирівняністю зерна; мають значну кількість суиввіть та високу їх фертильністю (озерненістю), генетично обумовлені параметри висоти рослини та кількості вузлів с зоні гілкування; характеризуються контрольованою тривалістю вегетаційного періоду, поєднаного із дружністю достигання, типом росту рослин, стійкістю до вилягання та осипання плодів; мають підвищені параметри посухостійкості та жаровитривалості.
\end{abstract}

Ключові слова: насіння гречки, сорти, сортові ознаки, генофонд, якість насіння, маса 1000 насінин.

Постановка проблеми. Збільшення виробництва продукції рослинництва можливо досягти декількома способами, але доступним і доцільним залишається лише шлях розвитку і впровадження високих наукоємних генетико-селекційних технологій, які здатні забезпечити оптимальний набір та співвідношення генів в новому сорті і оптимальну взаємодію генотип-середовище в зоні селекції. Тому для успішної селекції важливим $\epsilon$ наявність вихідного матеріалу, який сформувався в певних агрокліматичних умовах і володіє комплексом механізмів пристосування до певних умов середовища $[1,2]$.

Аналіз останніх досліджень і публікацій, у яких започатковано розв'язання проблеми. Гречка надзвичайно сприйнятлива для пристосування культура, яка завдяки людині була розповсюджена по території більшості регіонів світу (Євразії, Австралії, Африки, Америки Південної та Північної) і практично досягла кордонів зем- леробства. Її можна вирощувати скрізь, де безморозний період триває більше 60 днів і середньодобова температура повітря перевищує 17$18{ }^{\circ} \mathrm{C}$, а кількість місячних опадів становить 50 60 мм [3].

Таке географічне розповсюдження привело до значної різниці між зразками, вирощеними в різних регіонах світу, яка сформувалася під впливом факторів середовища і слугувала на перших етапах пристосувальним механізмом. Дослідженнями багатьох вчених встановлено специфічність формування селекційно важливих та господарськи цінних ознак в залежності від зони вирощування [4]. А. С. Кротовим при вивченні генофонду гречки території колишнього Радянського Союзу було здійснено розподіл колекційного матеріалу на 4 еколого-географічні групи: середньостиглу південну, скоростиглу північну, пізньостиглу приморську та середньостиглу гірську. Подальші дослідження підтвердили правильність цієї теорії і внесли до неї лише уточнення, але не змінили принципу. В назву групи автором було внесено важливу ознаку - тривалість вегетаційного періоду, яка в більшості випадків $\epsilon$ інтегруючою при визначенні цінності вихідного матеріалу для того чи іншого регіону. I хоч придатність до застосування вихідного матеріалу визначається напрямом селекції (на урожайність, якість продукції, високий гомеостаз плодоутворення, придатність вирощування за інтенсивною технологією, холодо- та посухостійкість, нектаропродуктивність, стійкість проти шкідників та хвороб тощо), тривалість вегетаційного періоду в більшості випадків $є$ визначальною характеристикою.

Особливо актуальною $є$ ця теза зараз - в умовах різкої зміни клімату. Незмінним і вирішальним для виробничників $є$ показник урожайності, але шляхи формування його в контрастних умовах середовища можуть бути абсолютно різними. Рослини можуть мати або стійкість до несприятливого фактора (високих температур або 


\section{СІЛЬСЬКЕ ГОСПОДАРСТВО. РОСЛИННИЦТВО}

посухи), або ж мати змогу уникати згубної дії цих факторів (шляхом більш ранньої сівби i формування врожаю до настання жорстких негативних умов середовища). Тому в селекції потрібно мати широкий діапазон вираження одного й того ж показника, наприклад, за тривалістю вегетаційного періоду, поєднаного з комплексом інших селекційних та господарськи цінних ознак. Вирішенню проблеми залучення до селекційної роботи різного за характеристиками матеріалу сприяють колекційні зібрання. В Національному центрі генетичних ресурсів рослин України накопичено колекцію гречки, яка складається із понад 2000 тисяч автентичних зразків, які $є$ представниками 23 країн світу із різних екологічних зон планети

Мета дослідження: виділення найбільш цінних зразків, які можна рекомендувати як джерела цінних ознак із підвищеними параметрами урожайності, продуктивності рослини, крупноплідності, що поєднується із високою вирівняністю зерна; мають значну кількість суцвіть та високу їх фертильність (озерненість), генетично обумовлені параметри висоти рослини та кількості вузлів у зоні гілкування; характеризуються контрольованою тривалістю вегетаційного періоду, поєднаного із дружністю достигання, типом росту рослин, стійкістю до вилягання та осипання плодів; мають підвищені параметри посухостійкості та жаровитривалості.

Матеріали, умови та методи досліджень. Дослідження виконано відповідно до договору між Полтавською державною аграрною академією та Устимівською дослідною станцією рослинництва Інституту рослинництва ім. В.Я. Юр'єва НААН та спрямовані на всебічну та повну оцінку колекційних зразків Національної колекції України за комплексом господарських та селекційно-цінних ознак. В умовах Полтавської області в період 2011-2017 років вивчено понад 300 зразків, походженням iз 15 областей України, 8 - Російської Федерації, а також матеріал із Білорусії, Польщі, Грузії, Німеччини, Франції, Литви, Кореї та Японії. Дослідження генофонду проведено відповідно до "Методических рекомендаций по изучению коллекционных образцов кукурузы, сорго и крупяных культур” [5], “Анализа структуры растения гречихи (Методические рекомендации)" [6], “Широкого уніфікованого класифікатора роду Гречки (Fagopyrum Mill.)" [7], "Descriptors for buckwheat (Fagopyrum spp.)" [8]. Створена за результатами вивчення інформаційна база містить дані про зразки за 14 ознаками, серед яких інформація щодо урожайності, продуктивності, кількості суцвіть на рослині, складові архітектоніки рослини (кількість вегетативних і генеративних вузлів на головному пагоні), крупноплідності, скоростиглості, висоти рослини та висоти прикріплення нижніх продуктивних суцвіть, параметрів нижнього міжвузля (довжини та товщини), стійкості до осипання, параметрів посухостійкості, жаровитривалості та ін.

Польові досліди розміщувалися в селекційнонасінницькій сівозміні Устимівської дослідної станції рослинництва, попередником був чистий пар і озимі зернові культури. Застосовувалася загальноприйнята технологія вирощування гречки. Метеорологічні умови, що складалися під час періоду вегетації, дозволяли в повній мірі оцінити потенціал зразків за показниками продуктивності рослин, якості зерна та адаптивними характеристиками.

Результати дослідження. Вся робота із залучення вихідного матеріалу в селекцію повинна бути спрямована на пошук зразків, що мають певний рівень вираження показників, значною мірою обумовлених генотипом [9, 10]. До таких показників належать продуктивність рослини, крупність зерен, тривалість вегетаційного періоду, висота рослини та формуючі іiі ознаки (довжина зони гілкування та зони плодоношення), а також індексні показники - індекс індивідуальної насіннєвої продуктивності (ІІНП - відношення маси зерна до загальної біомаси рослин), індекс озерненості (Оз.III - відношення маси зерна рослини до кількості елементарних суцвіть), індекс атракції (IА - співвідношення генеративної маси (зерна) до вегетативної маси) та, частково, кількість суцвіть.

Аналіз показника ваги зерна з рослини вказує не лише на значне різноманіття прояву його у різного за походженням колекційного матеріалу. Інтервал між мінімальним і максимальним рівнем продуктивності становить 3,08 г, за найменшої продуктивності 0,88, найбільшої - 3,96 г iз рослини. Підтвердженням цьому $є$ рівень варіювання ознаки, коефіцієнт варіації по групі вивчення склав $31,2 \%$, із розподілом за роками від 18,0 до 42,7 \%.

Кращою продуктивністю характеризуються зразки середньостиглої південної групи та скоростиглої північної, що можна пояснити кращою пристосованістю цього матеріалу до місцевих умов вирощування - високих температур і малої кількості опадів у період цвітіння та плодоутворення (табл. 1). 
СІЛЬСЬКЕ ГОСПОДАРСТВО. РОСЛИННИЦТВО

\section{1. Характеристика урожайних показників гречки звичайної (Fagopyrum esculentum Moench.)} різного еколого-географічного походження

\begin{tabular}{|c|c|c|c|c|c|c|c|}
\hline \multirow{3}{*}{$\begin{array}{c}\text { Назва } \\
\text { еколого- } \\
\text { географічної } \\
\text { групи } \\
\end{array}$} & \multirow{3}{*}{$\begin{array}{c}\text { Кількість } \\
\text { зразків, } \\
\text { шт. }\end{array}$} & \multicolumn{6}{|c|}{ Показники } \\
\hline & & \multicolumn{2}{|c|}{ Урожайність, г/м² } & \multicolumn{2}{|c|}{$\begin{array}{c}\text { Продуктивність } \\
\text { рослини, Г }\end{array}$} & \multicolumn{2}{|c|}{ Маса 1000 зерен, Г } \\
\hline & & середнє & $\min -\max$ & середне & $\min -\max$ & середнє & $\min -\max$ \\
\hline $\begin{array}{l}\text { Стандарт } \\
\text { (с. Українка) }\end{array}$ & & 279,5 & $201-368$ & 2,61 & $1,71-3,28$ & 28,1 & $26,9-30,3$ \\
\hline $\begin{array}{l}\text { Середньости } \\
\text { гла південна }\end{array}$ & 124 & 221,8 & $113,5-421,0$ & 2,06 & $1,07-3,96$ & 26,9 & $23,1-33,2$ \\
\hline $\begin{array}{l}\text { Скоростигла } \\
\text { північна }\end{array}$ & 96 & 214,1 & $109,4-327,0$ & 1,94 & $0,89-3,36$ & 25,9 & $22,8-30,1$ \\
\hline $\begin{array}{l}\text { Середньости } \\
\text { гла гірська }\end{array}$ & 22 & 202,3 & $101,0-282,1$ & 1,75 & $0,75-2,91$ & 25,8 & $23,7-31,0$ \\
\hline $\begin{array}{l}\text { Пізньостигла } \\
\text { приморська }\end{array}$ & 41 & 214,1 & $111,3-312,0$ & 1,90 & $0,93-3,23$ & 26,2 & $23,3-29,8$ \\
\hline $\begin{array}{l}\text { Зразки } \\
\text { далекого } \\
\text { зарубіжжя }\end{array}$ & 21 & 217,2 & $97,5-324,0$ & 1,86 & $0,88-3,10$ & 26,6 & $24,1-29,6$ \\
\hline $\begin{array}{l}\text { Середнє } \quad \text { за } \\
\text { групою } \\
\text { вивчення }\end{array}$ & 304 & 216,6 & $101,0-421,0$ & 1,96 & $0,88-3,96$ & 26,4 & $22,8-33,2$ \\
\hline
\end{tabular}

Серед зразків найбільшу продуктивність (понад 2,5 г) мали представники середньостиглої південної групи - UC0100975, UC0100979 із Полтавської обл.; UC0100622, UC0100625 із Харківської обл.; UC0100636, UC0100641, Ємельчинська із Житомирської обл.; UC0100650, UC0100649, UC0100653, Хоростківська із Тернопільської обл.; UC0101829, UC0101830 із Закарпатської обл., UC0101425, UC0101231, UC0101424, UC0101249 із Хмельницької обл.; UC0102200 із Рівненської обл.; UC0102206 (с. Селяночка), UC0102207 (с. Руслана) із Сумської обл.; скоростиглої північної групи UC0100286 (с. Світязянка) UC0101195 (с. Ілія), UC0102203 (с. Аметист), UC0102204 (с. Сапфір), UC0102205 (с. Фенікс) із Мінської обл.; UC0101768, UC0101781 із Гомельської обл.; UC0101796 із Могилівської обл.; UC0100045, UKR008:01687 (с. Батир) із Республіки Татарстан, UC0102180 (с. Ілішевская), UC0102181 (с. Інзерская) із Республіки Башкортостан.

До основних ознак, що характеризують технологічну цінність зерна гречки, відносять величину та вирівняність плодів, плівчастість та легкість обрушування оболонки, вихід крупи та ії поживну цінність. Маса 1000 насінин (крупність плодів), як і плівчастість, є ознаками, що значною мірою обумовлені генотипом. Більш вирівняними $\epsilon$ крупнозерні зразки (до $95 \%$ ), а оптимальною для переробної промисловості є маса 1000 насі- нин на рівні 28-30 г [9]. Вивчення в контрастних умовах середовища колекційного різноманіття зразків, розподіл їх за параметрами технологічності дає змогу стверджувати, що більш крупне, вирівняне зерно мають сучасні сорти, дещо менше i 3 більшим впливом на величину цього показника умов середовища - місцеві та стародавні сорти та форми. Серед екологічних груп більш крупноплідними виявилися зразки середньостиглих південної та гірської груп, а також зразки зарубіжного походження (табл. 1). Серед зразків кращим рівнем крупно плідності, поєднаної із вирівняністю, що забезпечує вихід крупи на рівні кращих стандартів (76-77 \%) вирізняються: із середньостиглої південної групи - UC0101742 із ІваноФранківської обл.; UC0101686 із Київської обл., UC0101155 (с. Космея), UC0101938 (с. Надєжда), UC0101939 (c. Мутант ВM-2615) із Хмельницької обл.; UC0101859 із Черкаської обл.; UC0100167, UC0100190, UC0100195, UC0100262 із Полтавської обл.; UC0101993 (с. Ярославна), UC0100501 (с. Ямпольська місцева), UC0101678 із Сумської обл.; UC0102172 із Одеської обл.; скоростиглої північної - UC0100839, UC0100840 із Орловської обл.; середньостиглої гірської - UC0100275 із Тюмені; пізньостиглої приморської - UC0100292 iз Амурської обл.; UC0100251, UC0100261 (c. Марія), UC0101755 із Приморського краю; зарубіжні зразки - UC0101927 із Грузії; UC0100949 із Кореї та ін. 


\section{СІЛЬСЬКЕ ГОСПОДАРСТВО. РОСЛИННИЦТВО}

За даними дослідників гречки, на звичайних весняних посівах урожайність гречки визначається кількістю зерен у суцвіттях на гілках першого порядку та стеблі, а в пізніх або повторних - у суцвіттях на стеблі. Важливим показником $є$ кількість суцвіть на рослині та їх озерненість, яка найвища на стеблі та гілках першого порядку [9]. Серед групи вивчення найбільшу кількість суцвіть на рослині мали зразки пізньостиглої приморської групи, дещо меншу - зразки середньостиглих гірської та південної груп, а найменша кількість суцвіть виявлена у зразків скоростиглої північної групи. Разом із тим, найбільш озерненими виявилися зразки середньостиглої південної групи та скоростиглої північної груп. Тому на наш погляд більш доцільним буде враховувати озерненість суцвіть як показник ефективності роботи генеративної сфери рослини. Проведені дослідження виявили зразки iз різних еколого-географічних груп, що мають високий рівень прояву та значну стабільність фертильності (озерненості) суцвіть: середньостигла південна група - UC0100975 із Полтавської обл.; UC0100622, UC0100625 із Харківської обл.; UC0100636, UC0100641 із Житомирської обл.; UC0100645, UC0100649, UC0100650 із Тернопільської обл.; UC0101826 (с. Полтавка 1) iз Чернігівської обл.; UC0101829 із Закарпатської обл.; UC0101273, UC0101435 із Хмельницької обл.; UC0102200 із Рівненської обл.; UC0102206 (с. Селяночка), UC0102207 (с. Руслана) із Сумської обл.; скоростигла північна група - UC0100286 (с. Світязянка), UC0101195 (с. Ілія), UC0102203 (с. Аметист) та UC0102204 (c. Сапфір) із Мінської обл.; UC0101768, UC0101771 із Гомельської обл.; UC0101791, UC0101796 із Могилівської обл.; UC0100045 iз Татарстану; UC0101867 із Республіки Алтай; UC0102180 (с. Ілішевская), UC0102181 (с. Інзерская) та UKR008:01687 (с. Батир) із Башкортостану, ін.

Останнім часом більшість науковців згоджуються із тезою актуальності застосування при виборі вихідного матеріалу індексних показників, що характеризують насіннєву продуктивність, озерненість рослин, індекс атракції тощо. Для гречки були показниками: індекс індивідуальної насіннєвої продуктивності (ІІНП - відношення маси зерна до загальної біомаси рослин), індекс озерненості (Оз.III - відношення маси зерна рослини до кількості елементарних суцвіть) та індекс атракції (IA - співвідношення генеративної маси (зерна) до вегетативної маси) $[4,9]$. Для дослідження колекційного матеріалу було взято індивідуальну насіннєву продуктив- ність та індекс озерненості. Отримані результати не дали можливості виявити специфічність прояву цих характеристик в залежності від належності до якоїсь із еколого-географічних груп, але iз групи вивчення було виділено зразки різного екологічного походження із високим рівнем цих показників та запропоновано розглядати їх як потенційно продуктивний матеріал для застосування в селекції: середньостигла південна група - UC0100975, UC0100979 із Полтавської обл.; UC0100622, UC0100625 із Харківської обл.; UC0100636, UC0100641 (с. Смельчинська) із Житомирської обл.; UC0100650, UC0100649, UC0100653 (с. Хоростківська) із Тернопільської обл.; UC0101725 із Львівської обл.; UC0101829, UC0101830 із Закарпатської обл., UC0101961 (с. Рубінова), UC0101249 із Хмельницької обл.; UC0102200 із Рівненської обл.; UC0102206 (с. Селяночка), UC0102207 (с. Руслана) із Сумської обл.; скоростигла північна група UC0100286 (с. Світязянка), UC0101195 (с. Ілія), UC0102203 (с. Аметист), UC0102204 (с. Сапфір), UC0102205 (с. Фенікс) із Мінської обл.; UC0101768, UC0101781 із Гомельської обл.; UC0101791, UC0101796 із Могилівської обл.; UC0100045, UKR008:01687 (с. Батир) із Республіки Татарстан, UC0101878 із Вологодської обл.; UC0102180 (с. Ілішевская), UC0102181 (с. Інзерская) із Республіки Башкортостан.

Для гречки звичайної (Fagopyrum esculentum Moench.) висота рослини $є$ характеристикою, яка тісно пов'язана із тривалістю вегетаційного періоду. Більш пізньостиглі форми формують і більш високі рослини 3 великою кількість міжвузлів на стеблі. Даними багатьох вчених доведено, що показник «кількість вузлів у зоні гілкування (ЗГС)» має чітку залежність рівня ознаки ЗГС від географічного походження сорту [4, 9]. При проведенні досліджень кількість вузлів в ЗГС варіювала від 23 до 8-9 штук. Із групи вивчення було виділено матеріал різного еколого-географічного походження, який характеризується висотою рослини на рівні до 110 см та має кількість вузлів у зоні гілкування стебла, яка не перевищувала 5 шт.: середньостигла південна група - UC0100544, UC0100549, UC0100560, UC0100562 із Чернігівської обл.; UC0100622 із Харківської обл., UC0100636, UC0100641 із Житомирської обл., UC0100649, UC0100653 (с. Хоростківська) із Тернопільської обл.; UC0101725 із Львівської обл.; $\mathrm{UC} 0101829$, UC0101830 із Закарпатської обл.; UC0101890, UC0101893 із Одеської обл.; UC0101960 (с. Антарія) із Київської обл.; UC0101982, UC0101220 із Хмельницької обл.; UC0102206 (с. Селяночка) із Сумської обл.; скоро- 


\section{СІЛЬСЬКЕ ГОСПОДАРСТВО. РОСЛИННИЦТВО}

стигла північна група - UC0101195 (с. Ілія) та

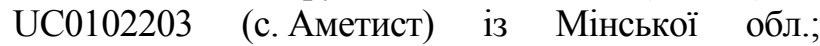
UC0100143 із Удмуртії UC0100804 із Московської обл.; UC0101878 із Вологодської обл.; UC0102180 (с. Ілішевская) із Башкортостану та ін.

Тривалість вегетаційного періоду - один із найвагоміших показників, що визначає господарську придатність сорту. Загальною тенденцією селекції гречки є створення скоро- та середньостиглих сортів [4]. Такі сорти при поєднанні в собі обмеженого типу росту та високої дружності достигання здатні реалізовувати свій урожайний потенціал у більш жорстких умовах вирощування. Господарники ж, змінюючи строки сівби, можуть зневілювати найбільш жорстку дію лімітуючого фактора (спеки чи відсутності опадів) або перенести іiі на найменш шкодочинні періоди росту i розвитку рослин.

Вже самі назви еколого-географічних групп (табл. 2) вказують на потенційну тривалість вегетаційного періоду у зразків, тому цей показник необхідно враховувати лише в комплексі 3 iншими характеристиками колекційного і селекційного матеріалу, наприклад, із дружністю достигання, типом росту рослин, стійкістю до вилягання та осипання плодів тощо.

Нині для селекційних досліджень потрібний вихідний матеріал, що характеризується підвищени- ми параметрами посухостійкості та жаровитривалості. В рамках виконання програми досліджень за напрямком вивчення посухостійкості та жаровитривалості проведено комплекс прямої оцінки впливу посухи та високих температур на рослини, а також непрямі показники - інтенсивність транспірації (г/м² год), водний дефіцит та водоутримуюча здатність, жаростійкості рослин (по методу Ф. Ф. Мацкова та при прогріванні насіння) та ін. За результатами вивчення виділено групу зразків, що мають підвищені парламенти посухостійкості та жаровитривалості (табл. 3).

Урожайність, як інтегральна ознака, складається iз декількох елементів, значно залежних від факторів зовнішнього середовища [4]. Пластичність сорту і пристосованість до місцевих умов, звичайно, знаходять своє відображення в кількісних показниках елементів структури врожаю. Основними структурними елементами урожайності сортів, що аналізувалися, $є$ маса зерна $з$ однієї рослини (продуктивність), маса 1000 зерен, довжина вегетаційного періоду зразків, а також показник висоти рослини.

Урожайність є основним показником, що характеризує цінність сорту. Вона найбільш повно відображає біологічні особливості сорту і його відношення до умов вирощування. Рівень вираження ознаки врожайності досліджуваних зразків представлено в таблиці 1.

\section{2. Докерела скоростиглості та середньостиглості гречки (тривалість вегетаційного періоду - до 72-х діб)}

\begin{tabular}{|c|c|}
\hline $\begin{array}{c}\text { Еколого- } \\
\text { географічна група }\end{array}$ & Джерела поєднання ознак \\
\hline $\begin{array}{l}\text { Середньостигла } \\
\text { південна }\end{array}$ & $\begin{array}{l}\text { UC0100330, UC0100334, UC0100339 із Полтавської обл.; UC0100520, } \\
\text { UC0100560, UC0101838 (с. Чернігівська 185) із Чернігівської обл.; UC0100615 із } \\
\text { Харківської обл.; UC0100645 із Тернопільської обл.; UC0100682 iз } \\
\text { Житомирської обл.; UC0101830 із Закарпатської обл.; UC0101858 із Черкаської } \\
\text { обл.; UC0101890, UC0101893 із Одеської обл.; UC0101911 (с. Дніпропетровська } \\
\text { 1) із Дніпропетровської обл.; UC0101319, UC0101322, UC0101487, UC0101273, } \\
\text { UC0101426, UC0101255, UC0101288, UC0101397, UC0101295 із Хмельницької } \\
\text { обл.; UC0102200 із Рівненської обл. }\end{array}$ \\
\hline $\begin{array}{l}\text { Скоростигла } \\
\text { північна }\end{array}$ & $\begin{array}{l}\text { UC0102203 (с. Аметист) із Мінської обл.; UC0101759, UC0101771, UC0101695 із } \\
\text { Гомельської обл.; UC0101796 із Могилівської обл.; UC0100068 із Республіки } \\
\text { Татарстан; UC0100115, UC0100804 із Московської обл.; UC0101843 із } \\
\text { Самарської обл.; UC0101867 із Республіки Алтай; UC0101878 із Вологодської } \\
\text { обл.; UC0102181 (с. Інзерская) із Республіки Башкортостан, UC0101916, } \\
\text { UC0102175 із Курської обл. }\end{array}$ \\
\hline $\begin{array}{l}\text { Пізньостигла } \\
\text { приморська }\end{array}$ & UC0101928 із Приморського краю \\
\hline Зарубіжні зразки & UC0101095 (c. Shinano 1) із Японії. \\
\hline
\end{tabular}




\section{3. Матеріал гречки із підвищеними показниками посухостійкості та жсаровитривалості}

\begin{tabular}{|c|c|c|}
\hline Ознака & Еколого-географічна група & Джерело ознаки \\
\hline \multirow{4}{*}{$\begin{array}{l}\text { Посухостійкість } \\
\text { (7-9 балів) }\end{array}$} & Середньостигла південна & $\begin{array}{l}\text { UC0100963 із Полтавської обл., UC0101152 із } \\
\text { Одеської обл., UC0101034 (с. Дождік) із Орловської } \\
\text { обл.; }\end{array}$ \\
\hline & Скоростигла північна & $\begin{array}{l}\text { UC0100370 (с. Лявоніха), UC0100369 (с. Альонушка) } \\
\text { iз Мінської обл., UC0100025 із Московської обл., } \\
\text { UC0101151, UC0101871 із Республіки Бурятія }\end{array}$ \\
\hline & Середньостигла гірська & $\begin{array}{l}\text { UC0101868 із Алтайського краю, UC0101915 із } \\
\text { Кемеровської обл. }\end{array}$ \\
\hline & Зарубіжні зразки & \begin{tabular}{|l} 
UC0100361 із Польщі, UC0101976 із Японії, \\
UC0101904 із Литви.
\end{tabular} \\
\hline \multirow{4}{*}{$\begin{array}{l}\text { Жаровитрива- } \\
\text { лість (7-9 балів) }\end{array}$} & Середньостигла південна & $\begin{array}{lllll}\text { UC0100963 із Полтавської обл., UC0101149 iз } \\
\text { Волинської обл. }\end{array}$ \\
\hline & Скоростигла північна & $\begin{array}{l}\text { UC0100025 із Московської обл., UC0100048 із Респуб- } \\
\text { ліки Татарстан, UC0101150 із Архангельської обл. }\end{array}$ \\
\hline & Середньостигла гірська & UC0101089 із Читинської обл. \\
\hline & Пізньостигла приморська & $\begin{array}{l}\text { UC0100130 із Приморського краю, UC0101091 із } \\
\text { Сахалінської обл. }\end{array}$ \\
\hline
\end{tabular}

У середньому за роки вивчення урожай зерна 3 одного квадратного метра по групах змінювався від 101,0 до 421,0 г. Серед сортового різноманіття гречки найбільш високою урожайністю відрізнялися найбільш пристосовані до місцевих умов зразки

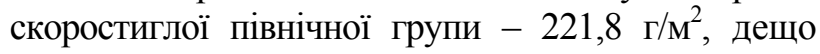
нижчою була урожайність у зарубіжних зразків

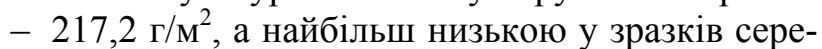
дньостиглої гірської групи - 202,3 г/м². Із групи вивчення за показником урожайності було виділено зразки, які мали не лише високий рівень цієї характеристики, але й мали високу стабільність іiї прояву: середньостигла південна група UC0100975, UC0100979 із Полтавської обл., UC0100622, UC0100625 із Харківської обл., UC0100636, UC0100641 (с. Смельчинська) iз Житомирської обл.; UC0100650, UC0100653 (с. Хоростківська) із Тернопільської обл.; UC0101829 із Закарпатської обл., UC0101425, UC0101231 із Хмельницької обл., UC0102200 iз Рівненської обл.; UC0102206 (с. Селяночка) та UC0102207 (с. Руслана) із Сумської обл.; скоростиглої північної групи - UC0100286 (с. Світязянка) UC0101195 (с. Ілія), UC0102203 (с. Аметист), UC0102204 (с. Сапфір), UC0102205 (с. Фенікс) iз Мінської обл.; $\quad$ UC0101768, UC0101781 із Гомельської обл.; UC0101796 із Могилівської обл.; UC0100045, UKR008:01687 (с. Батир) із Республіки Татарстан, UC0102180 (с. Ілішевская), UC0102181 (с. Інзерская) із Республіки Башкортостан та ін.
Висновки. Застосування комплексного підходу до оцінки та опису колекційного матеріалу різного еколого-географічним походженням за господарськими та селекційно-цінними показниками, використання польових та лабораторних оцінок дозволили виділити генофонд, який характеризується підвищеними параметрами урожайності, продуктивності рослини, крупноплідності, що поєднується із високою вирівняністю зерна; має значну кількість суцвіть та високу їх фертильністю (озерненістю), генетично обумовлені параметри висоти рослини та кількості вузлів с зоні гілкування; характеризується контрольованою тривалістю вегетаційного періоду, поєднаного із дружністю достигання, типом росту рослин, стійкістю до вилягання та осипання плодів; має підвищені параметри посухостійкості та жаровитривалості. Велику цінність має широке представництво у виділеному матеріалі зразків різних еколого-географічних груп, що дозволяє, проводячи селекцію на ту чи іншу ознаку, не звужувати генетичну базу новостворених сортів, шукати серед вихідних форм найбільш раціональне поєднання ознак та властивостей. Це особливо цінно в умовах швидкої зміни факторів оточуючого середовища, а також впровадження нових напрямів використання гречки i, як наслідок, пошуку серед генофонду альтернативних джерел із комплексом нетипових для сучасного сортового матеріалу характеристик. 


\section{БІБЛІОГРАФІЯ}

1. Рябчун В.К. Система генетичних ресурсів рослин України / В.К. Рябчун // Генетичні ресурси рослин : наук. журнал. - Х., 2004. - № 1. C. $8-15$.

2. Алексанян С. М. Агробиоразнообразие и геополитика / С. М. Алексанян. - С.-Пб. : ВИР, 2002. -363 c.

3. Генофонд и селекция крупяных культур. Гречиха / Н. В.Фесенко, Н. Н. Фесенко, О. И. Романова [и др.] ; под ред. В.А. Драгавцева. - С.Пб. : ВИР. - 2006. - 196 с.

4. Алексеєва О. С. Генетика, селекція і насінництво гречки: Навч. посібн. / О. С. Алексеєва, Л. К. Тараненко, М. М. Малина. - К. : Вища школа, 2004. - $216 \mathrm{c}$.

5. Кротов А. С. Гречиха // Методические рекомендации по изучению коллекционных образцов кукурузы, сорго и крупяных культур. - Л.: Издательство ВИР, 1968. - С. 37-44.

\section{ANNOTATION}

Trygub O. V., Liashenko V. V., Barabolia O. V. Selective value of environmentally distant samples of buckwheat of the National Collection of Ukraine.

Buckwheat is extremely receptive to adapt to the culture that was spread through the territory of most regions of the world (Eurasia, Australia, Africa, South and North America), and practically reached the limits of agriculture. It can be grown everywhere, where the frost-free period lasts more than 60 days and the average daily air temperature exceeds $17-18{ }^{\circ} \mathrm{C}$, and the amount of lunar rainfall is $50-60 \mathrm{~mm}$ [3].

This geographical distribution led to a significant difference between the samples grown in different regions of the world, which was formed under the influence of environmental factors and served in the early stages as an adaptive mechanism.

The article presents the results of the study of the buckwheat collection material of the National Collection of Ukraine of different ecological and geographical origin by economic and selectionvaluable indicators. The distribution of the gene pool of the study group is carried out depending on the ecological suitability of the varieties and forms. Of the variety, the most valuable samples are selected, which can be recommended as sources of valuable attributes with increased parameters of yield, plant productivity, and large-grain yield,
6. Бочкарёва Л. П. Анализ структуры растения гречихи // Методические рекомендации; под ред. Алексеёвой Е. С. и Гончарука А. В. - Черновцы, 1994. -45 c.

7. Тригуб О. В., Харченко Ю. В., Рябчун В. К., Григоращенко Л. В., Докукіна К. І. Широкий уніфікований класифікатор роду Гречки (Fagopyrum Mill.)/ Устимівка, 2013. - 54 с.

8. Descriptors for buckwheat (Fagopyrum spp.) / J. M. M. Engels, R. K. Arora. - Roma, Italy: IPGRI, 1994. $-48 \mathrm{p}$.

9. Тараненко Л. К., Яцишен О. Л. Принципи, методи і досягнення селекції гречки (Fagopyrum esculentum Moench.). - Вінниця : ТОВ «Hiлан-ЛТД», 2014. - 222 с.

10. Фесенко Н. В., Романова О. И., Алексеева $E$. C., Суворова Г. Н. Генофонд и селекция крупяных культур. Гречиха / под ред. В. А. Драгавцева. - СПб.: ГНЦ РФ ВИР, 2006. - Т. 5. - 196 с.

which is combined with high grain leveling; which has a significant number of inflorescences and high fertility (lacustrine), genetically determined parameters of the height of the plant and the number of nodes from the branching zone; it is characterized by the controlled duration of the growing season, coupled with the achievement's friendliness, the type of plant growth, resistance to shedding and sinking of the fruits; and it also has increased parameters of drought resistance and heat resistance, etc.

Of great value is the wide representation in the selected material of samples of various ecological and geographical groups, which allows selection by one sign or another not to narrow the genetic basis of newly created varieties, to search among the source forms the most rational combination of features and properties. This is especially valuable in the conditions of rapid change of environmental factors, as well as the introduction of new directions of use of buckwheat and, as a result, search of alternative sources with a complex of non-typical for a modern high-grade material characteristics among the gene pool.

Key words: seeds of buckwheat, varieties, varietal signs, gene pool, quality of seeds, weight of 1000 seeds. 